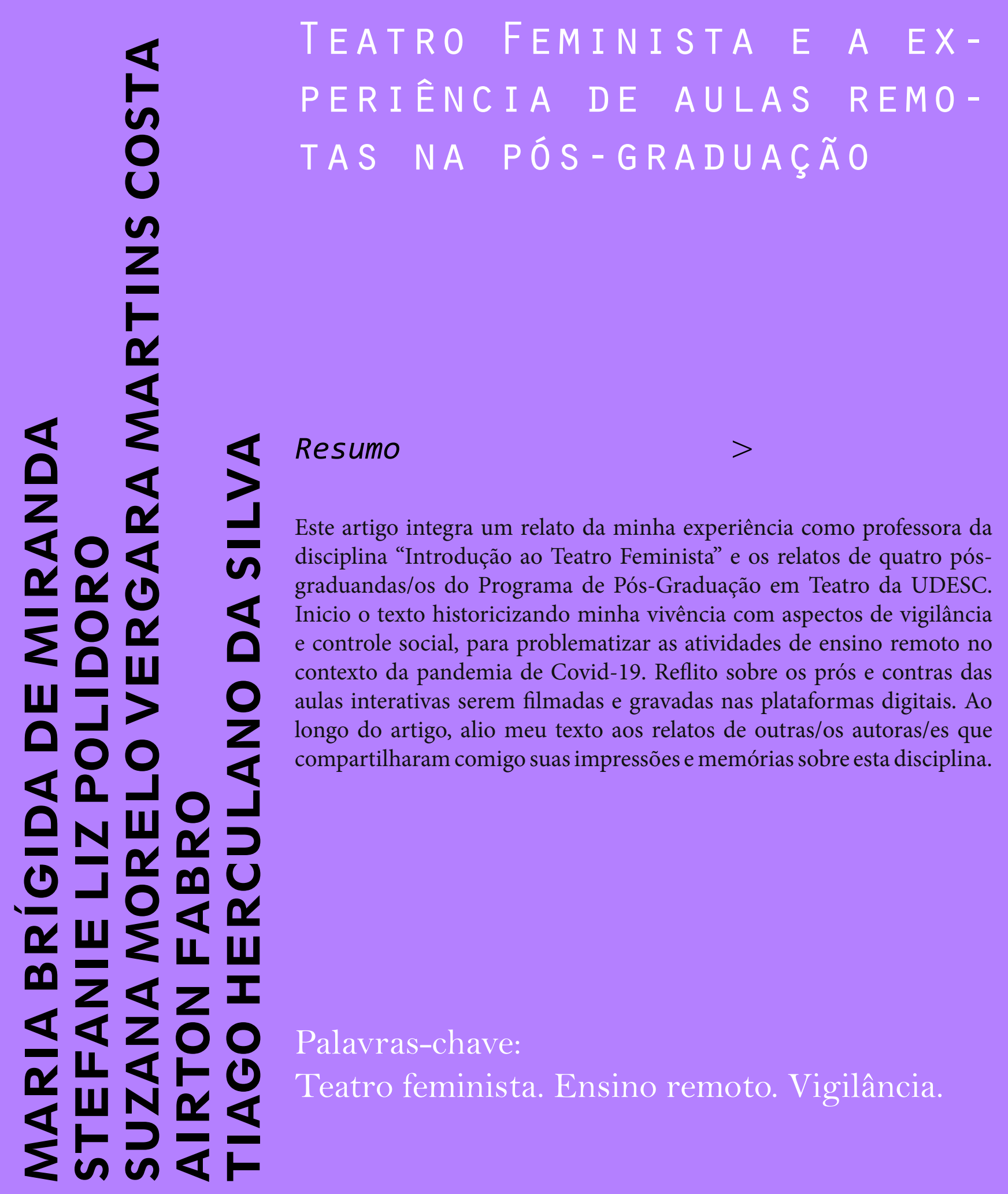




\title{
TEATRO FEMINISTA E A EXPERIÊNCIA DE AULAS REMOTAS NA PÓS-GRADUAÇÃO
}

\author{
Maria Brígida de Mirandal \\ Stefanie Liz Polidoro ${ }^{2}$ \\ Suzana Morelo Vergara Martins Costa ${ }^{3}$ \\ Airton Fabro ${ }^{4}$ \\ Tiago Herculano da Silva ${ }^{5}$
}

1 Doutora em Teatro pela La Trobe University. Professora Titular do Departamento de Artes Cênicas e Programa de Pós-graduação em Teatro (PPGT), Universidade do Estado de Santa Catarina. ORCID: 0000-00020828-8585. Email: brigidaudesc@ gmail.com.

${ }^{2}$ Doutora e Mestra em Teatro pelo Programa de Pós-graduação em Teatro (PPGT) da Universidade do Estado de Santa Catarina. Graduada em Teatro com ênfase em Interpretação pela UFRGS. Atualmente realiza o Estágio Pós-doutoral no PPGT/ UDESC. Atriz, bailarina e pesquisadora. Professora da Universidade Federal de Pelotas. ORCID: 0000-0003-4549-5556. Email: tefapolidoro@gmail.com.

${ }^{3}$ Mestranda em Teatro pelo Programa de Pós-graduação em Teatro (PPGT) da Universidade do Estado de Santa Catarina. Antropóloga de formação pela Universidade Federal de Santa Catarina. ORCID: 0000-0002-1333-5745. Email: suzanavergara10@gmail.com.

${ }^{4}$ Mestre em Teatro pelo Programa de Pós-graduação em Teatro (PPGT) da Universidade do Estado de Santa Catarina. ORCID: 0000-0002-46489847. Email: grairton@hotmail.com.

5 Doutorando em Teatro pelo Programa de Pós-graduação em Teatro (PPGT) da Universidade do Estado de Santa Catarina. Ator, autor, iluminador e diretor de formação pela Universidade Federal da Paraíba e Artista Plástico pela Universidade Federal de Campina Grande. ORCID: 00000001-6701-7075. Email: txchyagoserectus@hotmail.com.

\section{Corpo-memória}

Há décadas, deixei uma caixa com meus Long Plays (LPs) na casa da minha mãe. Com zelo e organização, ela reuniu todos os discos de vinil, descartados pelos muitos filhos e filhas, dentro de uma cômoda de madeira. Sobre o velho móvel, ela colocou também um aparelho de som três em um da marca CCE, que comprei com minha primeira bolsa de iniciação científica, no início dos anos de 1990. Houve uma época em que eu me sentava no chão frio para relembrar minha juventude, ficava contemplando os detalhes da arte das capas daqueles LPs enquanto ouvia na sequência as músicas do lado A, e depois as do lado B, com todo o chiado típico do fluir da agulha de metal sobre a negra superfície entalhada. Mas mesmo esse hábito ficou no passado. Com o indicador, deslizo sobre a tela do meu celular meu desejo de ouvir músicas sem que elas obedeçam a qualquer sequência, e de quebra assisto a videoclipes daqueles tempos idos. Relembro, choro, rio e, às vezes, compartilho o vídeo com alguém no WhatsApp e, de- 
pois de alguns dias, até me esqueço do que ouvi e vi. Mas me lembro de algumas coisas muito físicas. E penso que isso possa ser amparado por esta frase de Jerzy Grotowski "o corpo não tem memória, ele é memória” (GROTOWSKI apud WOLFORD, 211, 2010).

Sinto a memória ao digitar este texto. Ela vem com a sensação do calor do verão mineiro de 1984, quando me matriculei em uma escola de datilografia, que funcionava no porão de um casarão colonial. Aos 14 anos, me dedicava a treinar a força, a pressão e a velocidade de meus 10 dedos em máquinas mecânicas, para escrever um texto sem olhar para as teclas. Isso me salvou de uma situação quando, aos 24 , sentei-me pela primeira vez em frente a um computador da University of Exeter, na Inglaterra. Era outubro de 1994, as folhas avermelhadas de plátano caíam sobre o gramado do Drama Department, e eu sentia que minhas mãos relembravam sem esforço a posição de cada tecla enquanto eu aprendia a ter mais leveza na ponta dos dedos para digitar um essay no curso de mestrado para a disciplina Socialist Theatre. Meses depois de adaptar meu treino de datilografia para a digitação, a universidade me deu um código de acesso para eu mandar mensagens por um computador, localizado no laboratório de tecnologia do campus. Inauguraram lá uma comunicação pessoal mais avançada que o telegrama, ou fax símile, e sem que eu precisasse gastar minhas moedas no telefone público. Eu só não tinha, naquele momento, para quem mandar quaisquer mensagens eletrônicas, pois minha família e amigas nem sabiam da existência daquelas novidades promissoras: a internet e os e-mails.

\section{Corpo-carne}

Vivi na cidade de Exeter por exatamente um ano e dois meses, período em que os jornais ingleses se ocupavam de noticiar a temível "doença da vaca louca", uma síndrome de degeneração neurológica que atingia pessoas que haviam consumido carne de animais doentes. Depois de semanas morando em uma casa de estudantes, comprando e fritando grandes pedaços de bife, na cozinha comunal, meu inglês ficou bom o suficiente para entender os telejor- nais. Segundo as notícias da época, os bois estavam sendo alimentados pelos restos mortais de outros bois - matéria orgânica que não era possível vender, como miúdos e cérebro, eram transformados em ração. Não parei de comer carne naquela época, mas comecei a comprar carne com etiqueta de outros países. Eu não entendia o porquê de tantas pessoas na Inglaterra protestarem contra os maus-tratos sofridos pelos animais. Achava estranho ouvir os casos de ativistas que se acorrentavam aos caminhões que transportavam dezenas de bois. Eu comparava aquela questão animal à recente Chacina da Candelária, ocorrida em 1993, e pensava o seguinte: "Nossa, esses ingleses ficam se preocupando com o bem-estar animal, enquanto no Brasil há 'crianças-de-rua' sendo assassinadas'.

Ao caminhar pelas ruas daquela cidade traçada em forma de cruz pelo Império Romano, meu choque cultural era constante. A cada dia eu me deparava com assuntos e situações com os quais jamais havia lidado. Numa das minhas voltas do supermercado carregando minha sacola plástica cheia de filés, leite, chás e macarrão instantâneo, me deslumbrei quando a neve caiu úmida sobre o asfalto. Debaixo dos meus pés gelados, a grossa camada de asfalto e, sob ela, os túneis escuros das catacumbas dos cristãos. Subterrâneas, as celas vazias de corpos foram transformadas em atração turística daquela rica e conservadora cidade inglesa. Mas eu não me interessava pelo subterrâneo; eu olhava para o céu, admirando a brancura daqueles floquinhos dançando na brisa. Naquele dia, um colega da universidade mostrou-me sem muito gestual, apenas com um olhar despistado, uma caixinha de metal no alto de um edifício. Ele comentou da ação recente da prefeitura de instalar, a despeito dos protestos de vários grupos ativistas, câmeras de segurança. Pensei que aquilo era muito futurista, e fiquei refletindo como tudo era filmado se não havia nenhum "cameraman" visível. Logo comecei a cogitar que tal vigilância garantiria que não houvesse pequenos furtos, como os que aconteciam em São Paulo. Deduzi que as filmagens constantes eram boas, pois asseguravam a tranquilidade nas ruas. Um tempo depois, alguém me alertou que os cidadãos de Exeter tinham muitas reservas com os estudan- 
tes estrangeiros, principalmente os de origem asiática, africana e sul-americana, e que esse era um dos motivos de terem instalado câmeras de vigilância na cidade e no campus. Naquela ocasião, comecei a me perceber como "outra". Como se dizia na gíria daquela época, em que todos nós usávamos telefones públicos, "caiu a ficha" de que eu era uma pessoa "não branca" e potencialmente perigosa para aquela sociedade.

\section{Corpo-máquina}

Mas essa experiência não me impediu de continuar desejando morar "no estrangeiro", com a esperança de que "lá fora" eu viveria em um mundo melhor, com mais estabilidade financeira, menos violência e com as coisas funcionando bem. Em 1999, fui para a Austrália fazer Doutorado em Teatro na La Trobe University. Eu estava interessada no treinamento de atores e na estética do teatro físico, temas que, com a maior circulação de companhias estrangeiras, como o grupo dinamarquês Odin Teatret e a companhia francesa Royal de Luxe, pelos circuitos de festivais internacionais no Brasil, entusiasmava uma legião de jovens artistas e estudantes de teatro. No dia que celebrava dois anos da minha chegada, assisti pela televisão às imagens de aviões chocando-se contra as Torres Gêmeas, em Nova Iorque. Algumas semanas depois, recebi pelo correio um imã de geladeira, com números de disque-denúncia contra qualquer atividade suspeita de terrorismo, e os estrangeiros eram os maiores suspeitos. Melbourne, diferente de Exeter, era uma cidade cheia de câmeras de segurança, mas não apenas sobre os telhados dos edifícios - também nos corredores internos de prédios públicos e residenciais. Novamente, tudo me indicava que meu corpo, como pessoa latina, era um alvo (dentre outros) de vigilância e suspeição.

\section{Corpo-político}

Em 2017, criei a disciplina "Introdução ao Teatro Feminista” na categoria de Seminário Temático I, com quatro créditos e um total de 60 horas-aula, distribuídas em quinze semanas consecutivas. Em três edições, semestres 1/2017, $2 / 2018$ e $2 / 2019$, ofereci a disciplina no modo presencial para turmas de doze a vinte estudan- tes, a maioria mulheres, que cursavam Mestrado, Doutorado, ou estavam matriculadas como alunas especiais no Programa de Pós-Graduação em Teatro (PPGT), da Universidade do Estado de Santa Catarina (UDESC). Em publicações recentes (MIRANDA, 2020), relatei o propósito e o projeto da disciplina, os fundamentos teóricos, os conteúdos e as referências bibliográficas indicadas, além de procedimentos pedagógicos inspirados em práticas teatrais e epistemologias feministas, que conduzi tanto como idealizadora quanto como ministrante da disciplina. No último texto que escrevi sobre a experiência de conduzir esta disciplina, convidei ex-alunas/ os/es que cursaram a disciplina em algum dos três anos de edição a me enviarem por e-mail, ou WhatsApp, suas percepções e memórias, em formato de pequenos depoimentos e relatos.

Desde a primeira edição da disciplina "Introdução ao Teatro Feminista", organizei o conteúdo teórico e histórico sobre práticas teatrais feministas dos séculos XIX e XX de forma permeável e porosa às subjetividades e aos eventos. Para mim, a base do curso precisava estar ligada à noção de que "o pessoal é político". Deixe-me dar um exemplo: eu estava diante da instabilidade social, acentuada com o processo turbulento de impeachment da presidenta Dilma Rousseff, em 2016; por isso, busquei práticas feministas teatrais para refletir sobre os direitos políticos das mulheres. Organizei no cronograma a leitura dramática da peça sufragista O Voto Feminino (1890), escrita pela jornalista e sufragista brasileira Josephina Alvares de Azevedo. Se por um lado há uma questão histórica muito significativa revelada pelas pesquisas de Valéria Andrade Souto-Maior (uma comédia musical em prol do voto, escrita e encenada por uma mulher em pleno século XIX, no Teatro Recreio, da capital do Brasil), por outro, nós, brasileiras, testemunhamos desde 2013 a crescente onda de violência simbólica dos meios de comunicação de massa contra a primeira presidenta eleita da história do país. A imagem do corpo de Dilma foi criada e exposta, constituindo a visibilidade de uma "punição exemplar", nos termos foucaultianos. Dilma como corpo-imagem estampado em capas de revista e adesivos de carro foi objeto de estupro, de queima na fogueira como 
bruxa, de acusação de histeria. Ao ver tais imagens repetidas em tantos papéis e telas digitais, senti medo e horror, e sei que muitas outras mulheres foram atravessadas por essas emoções.

Como professora, minha resposta a tais imagens de violência contra ela foi buscar no teatro feminista as soluções de nossas antepassadas da cena. Compartilhei em sala de aula como Josephina respondeu pela escrita dramática a campanha política misógina feita na imprensa do século XIX. Sua peça O Voto Feminino defendia a emancipação das mulheres e o seu direito de votar e ser eleita - seu objetivo era convencer o público de mulheres e de homens do Rio de Janeiro a apoiarem a campanha pelo sufrágio feminino na Assembleia Constituinte do Brasil Republicano, ocorrida em 1891. Nas turmas da disciplina Introdução ao Teatro Feminista, eu organizei leituras dramáticas, seguidas de debate. A dinâmica da aula presencial nas três edições costumava ser a seguinte: eu abria a aula com algum exercício ritualístico de integração de grupo e ativação da memória. A seguir, tecia uma "herstory" do teatro, ao fazer uma palestra de aproximadamente 40 minutos entrelaçando o movimento feminista de Primeira Onda ao teatro feminista sufragista - do final do século XIX e início do XX. Estruturava o tema histórico segundo dois estudos de caso - a peça $O$ Voto Feminino, citada anteriormente, e a peça sufragista A Pageant of Great Women (1909), escrita pela atriz e dramaturga Cicely Hamilton (1872-1952), e encenada por sua parceira, a diretora, produtora e figurinista Edy Craig (1869-1947), com a companhia de atrizes feministas The Pioneer Players, no início do século XX, em Londres, na Inglaterra.

Após a palestra "herstory do teatro", eu aproveitava a empolgação da turma ao "conhecer nossas antepassadas do teatro" e convidava as/os/es alunas/os/es a se reunirem em equipes de 3 a 5 pessoas e prepararem uma leitura dramática de um trecho da comédia musical $O$ Voto Feminino. Esse sempre foi um momento de grande descontração, pois integrava o interva- lo de 20 minutos da aula de 4 horas, no qual a equipe era convidada a lanchar junto e entrelaçar as proposições de leitura. Por aproximadamente 1 hora, eu caminhava pelo nosso Centro de Artes com meu copo de chá observando aquele burburinho criativo das pequenas equipes. Um grupo se sentava no gramado com textos nas mãos, trocando palavras, ideias e cigarros; outro aproveitava as mesas da cantina para lanchar e definir quem leria qual personagem; outras equipes, entre um gole e outro de café, dialogavam sobre a história de Josephina, de Dilma e sobre suas questões pessoais em relação aos parentes conservadores. Era lindo observar aquela multiplicidade de corpos-memórias compartilhando ideias e dramas de família naqueles breves instantes. Então, na terceira parte da aula, as equipes apresentavam suas leituras dramáticas seguindo na sequência das cenas da peça. Alegria, entusiasmo, risos e aplausos eram acompanhados de um bate-papo, regado a mais chá e café, sobre a experiência de preparar a leitura e realizá-la, assim como sobre as questões pessoais e políticas que emergiam e os sentimentos que ficaram. Ao final eu fazia alguma dinâmica ritualística de encerramento da jornada do dia - um círculo em que nos posicionávamos de pé e de mãos dadas, respirávamos juntas/os/es e cantávamos, ou lançávamos uma palavra sobre o sentimento que nos permeava naquele momento.

Assim, a disciplina Introdução ao Teatro Feminista mostrou-se em suas reedições como um campo potente de diálogo com o tempo presente. Mas foi além disso. Também foi um lugar de experimento coletivo, em resposta ao fechamento dos espaços sociais, fora e dentro da instituição acadêmica. Não cabia ignorar o avanço contemporâneo da extrema-direita, principalmente após estudar o fenômeno denominado "teatros feministas". Estávamos e estamos fazendo práticas feministas na academia em um estado que proibiu por decreto o uso da linguagem neutra ${ }^{6}$ e no qual representantes estaduais combatem abertamente os estudos feministas.

\footnotetext{
6 “Governo de SC proíbe linguagem neutra em escolas públicas e privadas". G1 e NSC. Santa Catarina, 18 jun. 2021. Disponível em: https://g1.globo.com/sc/santa-catarina/noticia/2021/06/18/governo-de-sc-proibe-linguagem-neutra-em-escolas-publicas-e-privadas.ghtml.
} 
Minha tática para não sucumbir ao desespero e à depressão que se abateu sobre nós, da comunidade universitária, após as eleições presidenciais de 2018, foi estimular com mais afinco que as experiências pessoais fossem compartilhadas pelo grupo de pessoas matriculadas na disciplina. Nos debates, exercícios artísticos e artigos, senti que as alunas, os alunos e es alunes abriam para o pequeno círculo de pessoas ali reunidas seus sentimentos, dúvidas, vivências e reflexões pessoais. Compartilho a seguir o relato vívido de Suzana Vergara, mestranda em Teatro, que cursou a disciplina ${ }^{7}$ no modo presencial em 2019:

Participar da disciplina "Seminário Temático: Introdução ao Teatro Feminista" foi fundamental para a minha formação enquanto artista e pesquisadora. Ali encontrei um lugar de conhecimento e de fazer de práticas feministas. A começar já em meu primeiro dia de aula, quando as professoras Dra. Maria Brígida de Miranda e Dra. Daiane Dordete nos convidaram para partilhar de um lanche e cantar uma canção em roda. Nos apresentamos dizendo nosso nome e o nome de nossas avós, ou de mulheres ancestrais importantes para nós. Relembrando figuras de mulheres guerreiras e imprescindíveis.

Neste dia, fomos para a parte externa do Centro de Artes, na área conhecida como Teatro de Arena, e refizemos o círculo que havíamos feito pouco antes na sala de aula. Agora fora de uma sala de aula, estávamos em um teatro. Saudamos em canção o céu, a estrela do mar, a noite que vem, a terra e todos os pontos do céu. As aves, os bichos do chão, os peixes e quem mora no mar. Saudamos quem vai chegar. Saudamos quem vai partir. Saudamos quem tá aqui e pedimos para a senhora: me dá tua mão. A senhora, esta do futuro.

Depois nós fomos convidadas e convidados a dizer e memorar mulheres atrizes, dramaturgas, figurinistas, mulheres do teatro, mulheres artistas. No começo não foi uma tarefa fácil, mas logo estava feliz memorando mulheres artistas próximas de mim. A turma já havia se espalhado por uma grande parte do pátio e logo voltamos para nosso círculo, agora ainda mais junto e próximo. Em acolhimento. Em aconchego. E novamente nos apresentamos.

Somos as netas de todas elas, pensamos. De volta à sala de aula n. ${ }^{\circ} 8$, tivemos a apresentação do plano de ensino da disciplina. A Mãe Cabra. O teatro pensado de um de seus primórdios. Quem saudamos? A pintura de Tereza Costa Rêgo. Os festivais. As saudações. A escrita para ser cantada em coro... O que faziam as mulheres de Atenas? O esquecimento. O silenciamento. Por que não nos lembramos de Praxilla? A luz do sol. Os pepinos frescos. Que deus é este? As peras, as maçãs. As estrelas e o luar. Onde foram parar os coros? A pluralidade de histórias. Por que vejo a poesia de Safo? A escrita. As personagens mulheres. As mulheres atrizes. Os novos movimentos sociais. A colcha de retalhos. Uma leitura dramática. A proposta de uma aula dinâmica.

Aquela introdução de como seria nossa abordagem sobre o teatro feminista ao longo daquele semestre havia indicado para mim quais seriam as expectativas para a disciplina: descobrimentos, compartilhamentos, cuidados e muitos aprendizados.

Então começamos a nos encontrar todas as terças-feiras, às $18 \mathrm{~h}$, no Centro de Artes da Universidade do Estado de Santa Catarina, para conhecermos e refletirmos sobre um teatro, ou melhor, sobre teatros feministas, no contexto global, brasileiro e desterrense. Para mim foi muito importante e fundamental para meus aprendizados ao longo da disciplina, além da excelente bibliografia proposta, a dinâmica da aula e como elas eram mediadas e conduzidas. Como já tinha visto na primeira aula, o lanche fraterno, o acolhimento, a escolha por outras formas de aprendizado, o fazer artístico, o cuidado e a história viva de mulheres seguiu ao longo de todo o semestre. As professoras se utilizaram das mais variadas dinâmicas que fugiam do método tradicional de aula expositiva, tornando as aulas momentos agradáveis e de intenso aprendizado.

Nas aulas seguintes, vimos filme, fizemos uma leitura dramática em grupo, nos divertimos encenando sobre a história das mulheres e os primórdios dos movimentos feministas, conversamos com a professora Dodi Leal, participamos um mês inteiro da Mostra Rosa Teatral vendo trabalhos de atrizes e atores que dialogavam com os conteúdos trazidos na disciplina. Conversamos com o Coletivo NEGA sobre seu trabalho e os feminismos negros, conversamos com Fernanda [Magalhães] sobre sua performance e a sociedade gordofóbica em que vivemos e no final da disciplina ainda pudemos nos aventurar mais pelo palco e pela arte do teatro, produzindo conteúdo para a Jornada Feminista. Foram momentos de grande aprendizado, pois dialogamos com os conteúdos teóricos acerca do teatro, do teatro feminista, da história das mulheres e dos movimentos feministas, segundo nossas experiências práticas e de nossa vontade de fazer teatro (COSTA, 2020).

${ }^{7}$ Em 2019, planejei e conduzi a disciplina em colaboração com minha colega Dra. Daiane Dordete Steckert Jacobs (PPGT/UDESC). 
Para mim foi impactante observar como as subjetividades são profundamente políticas. Podemos lembrar como esse entrelaçamento foi lançado por Carol Hanisch no icônico artigo "O pessoal é político" (1969), no qual defendeu que o relato pessoal nos grupos de "despertar da consciência", estava agindo em prol da conscientização política sobre as relações de poder a que as mulheres estavam submetidas. Foi possível perceber que, também no campo do ensino do teatro, ao estimular o espaço para o "pessoal", houve uma transformação pronunciada das produções artísticas: elas se tornaram mais políticas! Quanto mais pessoal, maior era a densidade e visibilidade das raízes políticas de cada cena, palavra, silêncio e gesto escolhidos.

Considerando a combinação da leitura de textos sobre teatros feministas com a possibilidade de falar de si, algo novo surgiu ao longo do curso. Eram impulsos criativos ferozes e amedrontados - mas que, amorosamente, fomos nutrindo em sala de aula, no grupo, no círculo, por meio de conversas, com pausas para lanches compartilhados, exercícios teatrais e meditativos, canções em roda, música ao vivo para curar a dor e a mágoa dos embates com familiares e amigos durante o processo eleitoral de 2018 - e tempos de pausa e repouso... Nos três anos de disciplina Introdução ao Teatro Feminista no formato presencial, vi muitas cenas, performances, dramaturgias, danças e vivências frescas, apaixonadas, dolorosas e transgressoras. Testemunhei o nascimento de um corpus de teatro feminista, em pequenas salas no campus Itacorubi. Por ter os prédios e salas fundadas sobre o aterro de um mangue, nosso corpo instintivamente se lembra que há lodo, água salgada e lama preta minando de vida o concreto.

\section{Corpo-enclausurado}

Em março de 2020, com o advento da pandemia da Covid-19 no Brasil e das medidas sanitárias de isolamento social, as aulas presenciais da UDESC foram suspensas. Retornamos em maio deste mesmo ano às aulas em modo remoto, por meio de plataformas que nos permitem acessar vários documentos e gravar nossas aulas síncronas, ou mesmo disponibilizar arquivos de fotografia, textos e vídeos para aulas assíncronas. $\mathrm{O}$ panóptico, descrito por $\mathrm{Mi}-$ chel Foucault, e o projeto do claustro em permanente estado de vigilância nunca me pareceu tão real. As pessoas que se encontrariam no café e se dariam as mãos no espaço de arena do Centro de Artes foram capturadas em imagens digitais. Nossos corpos foram enquadrados em células dispostas na tela. Como não se lembrar da obra foucaultiana Vigiar e Punir, mais especificamente de seu detalhamento das tecnologias disciplinares: o esquadrinhamento do espaço, o controle do gesto, do tempo, do pensamento?

Busquei refúgio em uma casa imersa na areia e rodeada por plantas e animais. Como uma pessoa exilada em uma bolha, eu ministrei a disciplina olhando para um tela e vendo outras trinta pessoas na mesma condição. $\mathrm{O}$ curso, em seus quinze encontros semanais, suas sessenta horas, foi capturado pela rede digital, para além das nossas próprias máquinas, nossos computadores pessoais. Se em 2019 bradamos contra o projeto de lei ${ }^{8}$ que permitia que alunos gravassem e denunciassem os profissionais da educação, em 2020, aceitamos sem medo as gravações de todas as nossas atividades de ensino. Nossas vozes e imagens tornaram-se memórias de nuvens imateriais. Se o corpo grotowskiano é memória, como é o corpo no qual estão as memórias de milhões de pessoas? Teria gênero esse corpo-arquivo da disciplina Introdução ao Teatro Feminista, que ministrei em 2020?

"Estranhamento" poderia ser o verbo para mantermos uma incansável problematização das relações humanas, na situação da existência panóptica. Como exercer no meio remoto o grupo de acolhimento que permite que o pessoal-político manifeste-se, sem risco de ser ameaçado por um regime futuro?

\section{Corpo-coletivo}

Reflito sobre os dilemas deste momento

\footnotetext{
8 "Novo projeto de Escola sem Partido permite que aluno grave professor". DC:. NSC Capa. Educação. 05 fev. 2019 22h02. Disponivel em: https://www.nsctotal.com.br/noticias/novo-projeto-de-escola-sem-partido-permite-que-aluno-grave-professor.
} 
histórico da pandemia, especialmente entre março de 2020 e abril de 2021, quando o processo de vacinação ainda não tinha sido iniciado e a maioria das instituições escolares estavam fechadas. Quando ministrei a disciplina em 2020, percebi o quanto o aparato tecnológico agregou pessoas em diferentes localidades do país. Vale destacar que a tecnologia das plataformas de teleconferência me possibilitou organizar um cronograma de aulas por meio do qual a cada semana recebíamos uma palestrante convidada de outro estado e instituição. Foram encontros com mulheres da prática teatral cujos trabalhos artísticos e/ou acadêmicos dialogam com práticas feministas.

As aulas tinham muitos participantes de diferentes cidades e estados conectados simultaneamente. De fato, o PPGT agrega, desde sua criação, em 2000, estudantes do interior do estado de Santa Catarina e da região Sul do país. Nos últimos anos, por conta de suas linhas de pesquisa, pontuações institucionais e programa de cotas, além dos atrativos da cidade turística, há um crescente número de estudantes das regiões Norte, Nordeste e Centro-Oeste. Mas foi significativo que pessoas sem vínculo com o curso se inscreveram como alunos/as/es especiais, considerando que as aulas no modo remoto permitiram que pessoas de outras localidades e sem vínculo institucional cursassem a disciplina sem o ônus de ter que se mudar, ou mesmo viajar semanalmente para Florianópolis. Assim, as aulas no modo remoto propiciaram um ambiente de polifonia de falas, sotaques e experiências regionais específicas.

\section{Corpus feminista para além da catego- ria mulher}

Outro aspecto que me chamou atenção na edição de 2020 foi o número crescente de homens que buscaram o curso. Além do caráter quantitativo, eu gostaria de refletir sobre os desdobramentos da presença masculina nessa prática de ensino do teatro feminista. Ao se pensar em práticas feministas, devemos considerar que a presença ou ausência masculina e a proporção entre homens e mulheres impactam as dinâmicas relacionais em sala de aula. Trago a seguir o relato de Stefanie Liz Polidoro, que cursou a dis- ciplina em 2017 e comentou em seu texto sobre a presença masculina em um grupo majoritariamente feminino:

Fui aluna da disciplina "Introdução aos Estudos de Teatro Feminista", ministrada pela professora Dra. Maria Brígida de Miranda, no PPGT da UDESC, no ano de 2017. Lembro-me de estudarmos atrizes, diretoras, dramaturgas e pesquisadoras que desenvolveram trabalhos importantes ao longo da história do teatro, muitas vezes sozinhas, outras vezes em parcerias com homens, e que na maioria das vezes não receberam os devidos créditos tal qual eles receberam - como o caso de Franca Rame e Dario Fo.

Além do protagonismo das mulheres no teatro - ouso dizer que foi a primeira vez que estudei sobre mulheres do teatro na academia -, o que me chamou atenção também foi a maneira como a professora conduziu a disciplina. Não éramos apenas mais uma turma do Programa de Pós-Graduação em Teatro... Formávamos uma espécie de comunidade na qual uma estudante contribui com a outra... Aliás, essa era uma das preocupações de Brígida: a construção colaborativa entre as estudantes, uma das características dos movimentos feministas, buscando fugir da lógica de relação patriarcal e capitalista, marcada por concorrências e individualismos, e prezando pela integração e pelo acolhimento de todas no grupo. (Digo "as" estudantes, porque a turma era formada majoritariamente por mulheres, contando apenas com a participação de dois homens).

Foi uma disciplina que me ensinou muito, tanto pelo conteúdo quanto pelas abordagens, e que serve de referência para as práticas pedagógicas que elaboro (POLIDORO, 2020).

É certo que apontei em trabalhos anteriores (MIRANDA 2010) o valor de espaços ginocêntricos para práticas teatrais feministas. Como a disciplina estimula a trança entre o pessoal e o político, a memória e as ações presentes, as antepassadas e nós mesmas, um ambiente só de mulheres tende a promover um sentimento de proteção e acolhimento. Porém, no âmbito de uma disciplina acadêmica em uma instituição pública, tal estratégia poderia ser considerada um cerceamento. O fato é que, nunca limitei o número de matrículas nem criei quaisquer impedimentos para as pessoas interessadas, e a cada edição observo um tímido mas crescente aumento da presença masculina 
em sala de aula. Assim, na edição de 2020, o número de homens matriculados subiu para 9 , em uma turma de 36 estudantes.

Ao final da disciplina, como de praxe, convidei os/as/es alunos/as/es a escrever relatos sobre suas experiências. De posse deles, recentemente escrevi um texto que urde os relatos de várias mulheres e alguns homens da pós-graduação em teatro que cursaram a disciplina em diferentes edições. Para essa seção do artigo, eu trouxe o depoimento dos doutorandos Airton Fabro e Tiago Herculano da Silva, porque eles demonstram o impacto do curso em suas percepções para além do teatro. Fabro, que mora em uma pequena cidade no interior do Rio Grande do Sul, coordena e dirige um grupo de teatro de jovens para o qual levou a discussão feminista que realizávamos em sala de aula. O desdobramento foi a criação de uma peça veiculada no Youtube. Foi comovente ver como Fabro, em uma das aulas remotas, fez uma performance em homenagem à bisavó que era benzedeira e parteira, e em outra aula convidou a filha para participar e falar sobre os textos feministas da disciplina que estavam sendo compartilhados por ele com o grupo de teatro. Apresento a seguir o seu texto-relato sobre a sua experiência na disciplina:

Pode-se dizer que a disciplina Introdução ao Teatro Feminista, ministrada pela Profa. Dra. Maria Brígida de Miranda, foi um encontro teatral místico que nos permitiu uma vivência experimental, científica e espiritual. Em sua disciplina, foi possível uma aproximação dos mais pertinentes movimentos históricos femininos, das heroínas que sobreviviam formando uma rede de proteção entre as mulheres como forma de resistência. Nas aulas, entramos em contato com a obra Calibã e a Bruxa, de Silvia Federici, sobre a qual vou me deter. A obra descreve os horrores sobre a mulher na Idade Média, vindos do abuso do poder, do machismo e até mesmo das instituições religiosas, dentro do contexto europeu. Isso me levou a refletir sobre as ancestralidades das mulheres que vivem na região que abrange o município de Machadinho, norte do Rio Grande do Sul, onde eu moro, localidade em que cerca de $80 \%$ da população é originária da imigração europeia.

Provavelmente, muitos de nós somos descendentes das "bruxas" perseguidas, das muitas que foram queimadas, das mulheres que foram estupradas por filhos de famílias ricas com o consentimento do governo e da própria Igreja Católica na Idade Média. As atrocidades de um poder manipulador que colocou a mulher no centro dos conflitos, sem terras, com filhos que dificultavam a locomoção, fizeram com que se tornassem vítimas da miséria. As bruxas eram mães que faziam os seus próprios chás de cura natural e chás abortivos contra estupros consentidos. Eram as parteiras que tinham o controle da reprodução feminina.

A partir dessas parteiras, faço um recorte que me provocou a criar artisticamente um ritual teatral em que me coloquei nesse lugar de representatividade dentro do teatro, com base na minha própria história. Minha bisavó Rosa Rech, conhecida como Nona Rosinha, imigrante italiana, foi parteira e realizou aproximadamente 600 partos na região, inclusive o meu, que foi o último parto feito por ela, encerrando um ciclo. A cada parto realizado, minha avó acendia uma vela para Nossa Senhora do Bom Parto, cujo dia é comemorado em 18 de dezembro, por destino, o dia em que faleceu.

As parteiras tanto aqui no Brasil como na Europa foram afastadas pela inserção do homem médico, o que masculinizou a reprodução. Contrapondo isso, acredito que a mulher deva buscar e conquistar espaços que lhes pertençam, a exemplo de guerreiras como Joana D’Arc e suas conquistas na França, Teresa de Ávila, a irmã Carmelita, líder de um movimento e reforma de mulheres, além de tantas outras mulheres guerreiras, como as dos movimentos sufragistas, que ainda hoje inspiram uma dramaturgia feminista. Isso prova que as maiores conquistas para a emancipação feminina se deram por meio de lutas e de muita garra, por isso as mulheres são tão necessárias.

A partir de então, pensando num contexto de teatro feminista, propus um exercício em busca das narrativas ancestrais femininas das atrizes do Grupo Aldeia Teatral, no qual trabalho como diretor. Nesse projeto, reuni três atrizes, sendo uma delas minha filha Ana Laura Pozzer Fabro, junto com as suas colegas Andressa Maso e Tainá Fraron. O fato de trabalhar com a minha filha sobre teatro feminista me gerou muitas incógnitas: de que maneira me compreender e me situar como homem num teatro que propõe uma luta em prol das mulheres, daquelas que estão interligadas com a minha vida? Pensar na minha filha e inseri-la numa luta por condições dignas de uma mulher imagino que seria um dos maiores objetivos da minha vida. É como se o ciclo continuasse, de geração em geração, de guerreiras para guerreiras, em que o meu corpo masculino agisse somente como um condutor de resistências femininas, dos "bruxismos" da minha bisavó 
para a minha avó, e agora para a minha filha. As lutas continuam transcendendo gerações, gêneros e corpos, que resultaram na criação de uma cena teatral que representasse essas mulheres: "As Bruxas do Colonialismo".

Ao trabalhar as ancestralidades das atrizes, percebeu-se como ainda as bruxas persistem e resistem em tempos atuais e como ainda vivem numa posição de fragilidade, necessitando de proteção. Das atrizes, por exemplo, Tainá é neta de Salete Rodrigues Grison, mulher indígena que, ao se casar com um imigrante, herda de sua nova família uma vida de preconceito por ser uma mulher nativa, tendo sido várias vezes tratada como "bugre" - expressão pejorativa herdada da cultura europeia em referência às bruxas na Idade Média. Ana Laura, bisneta de Rosa Pieri (in memoriam), minha avó por parte de pai, abdicou dos prazeres da vida para gerar seus filhos, tendo 21 gestações, todas de parto em casa. Ela foi uma bruxa que criou os filhos à base de ervas naturais, nunca precisando levá-los ao hospital. Temos ainda Andressa Maso, neta de Noile Maso, curandeira que ainda hoje prepara xaropes e óleos medicinais com plantas como forma de sobrevivência.

São histórias fortes que estão nos emancipando, emancipando as atrizes, as netas e bisnetas de bruxas. Descendentes de mulheres que tinham uma relação com a natureza, que viviam em rede de proteção e que hoje se tornam inspiração para refletir artisticamente as bravuras feministas e, com isso, questionar o machismo e o capitalismo que ainda na atualidade aniquilam as redes femininas (FABRO, 2021).

Este relato, a meu ver, explicita um processo de "despertar da consciência". Trata-se de um homem que passa a perceber e a criar narrativas sobre as mulheres da família, que passa a ser afetado ao rememorá-las e então se sente pertencente também à causa feminista. Um processo similar vejo no testemunho de Tiago Herculano da Silva, que, ao final do curso, expressou sua insegurança sobre se ele, como homem, poderia também trazer um relato pessoal. O trabalho de Silva entrelaçou a sua reflexão sobre uma performance da artista Maria Angélica, cuja temática é a maternidade, com a sua experiência de ser filho de uma mulher que sofreu o rechaço da família e da comunidade por ter sido mãe depois dos 40 anos, ou seja, em uma idade considerada "avançada".

Durante minha formação, seja graduação na
UFPB ou mestrado na UFRN, era bastante comum termos um texto central que conduziria os estudos da disciplina e outros complementares que poderiam ajudar caso o aluno desejasse. Esse texto principal seria usado em todas as aulas para trabalhar o assunto abordado na disciplina e não tínhamos tanto acesso a vivências e falas de outras artistas nacionais sobre o assunto. No caso da disciplina Introdução ao teatro feminista, ministrada pela Prof. ${ }^{a}$ Dr. ${ }^{a}$ Maria Brígida de Miranda, pude perceber que a disciplina não continha um texto central a ser utilizado como condutor de todas as aulas.

No princípio me senti perdido sem saber o que ler ou estudar para ter uma boa base de entendimento e referências sobre o teatro feminista, mas a falta de uma referência textual central terminou me incentivando a buscar minhas próprias referências e construí-las em comunhão àquilo que me afetava. Com o advento da pandemia, causada pela Covid-19, tivemos aulas remotas e isso facilitou termos acesso a entrevistas com artistas de diversas partes do país. Comecei a perceber que quando a professora realizava esses convites para artistas falarem sobre seus trabalhos, suas pesquisas e suas experiências, estávamos ouvindo falas importantes que contavam a realidade do teatro feminista na atualidade, levantavam suas pautas e nos provocavam sensibilidades. Essas falas davam voz às artistas e forneciam ao aluno uma ampla referência de vivência e compartilhamentos de saberes que vão além da referência textual.

Ouvir a pesquisa do outro se tornou algo mais forte e fundamental para nossa formação que apenas ler um texto e usá-lo para escrever um trabalho final na disciplina. Foi o ouvir, estimulado pela disciplina, que pude perceber nas falas as referências que eu precisava. Ao ouvir as falas de Maria Angélica Costa sobre o corpo feminino que engravida tardiamente, percebi a ligação de sua obra artística com a história de minha família, algo que não perceberia apenas estudando um texto. A voz da Angélica ecoou em minha vivência familiar e me fez buscar referências sobre esse assunto que me tocava. Ao me interessar em estudar o corpo da mulher grávida em idade avançada, pude perceber como esse corpo está relacionado ao corpo controlado socialmente.

Ao longo da disciplina estudamos a obra Vinegar Tom e vários questionamentos foram colocados para o corpo da artista em nossas conversas. Nessas conversas em aula, alguém citou um texto e terminamos procurando sobre ele. $\mathrm{O}$ espaço do diálogo e do ouvir o outro pode propiciar o estímulo que precisamos, como alunos, de criar nossas referências. Diálogos que reverberaram 
e estimularam a busca por outras mulheres que falassem sobre essa corporeidade feminina e o processo da gravidez. Assim, procurei textos como o de Andréa Osório - O corpo da bruxa para entender os processos desse corpo feminino nas relações de poder que envolvem o útero; que envolvem o controle do corpo; que envolvem a gravidez tardia. Aos poucos fui percebendo e criando estratégias de como buscar novas referências para a temática que me afetava e que gostaria de abordar em minhas falas.

Talvez não tivéssemos esse estímulo se a disciplina fosse presencial, pois é possível que não tivéssemos acesso a tantas falas de tantas mulheres que moram em locais diversos do Brasil. Teatro feminista, para mim, é sensibilidade, e essas falas falavam sobre sensibilidades. Elas nos ensinavam por meio do sensível. Vale salientar que recebíamos também artigos fornecidos pelas artistas entrevistadas em aula. Tínhamos textos delas que podíamos ler e dialogar com suas falas. Acho isso muito relevante, pois conversar com essas artistas e autoras se torna fundamental para o melhor entendimento da pesquisa e sua relevância, além de estarmos não apenas divulgando o trabalho prático e dando voz a elas, mas fazendo dessas escritas e sensibilidades nossas referências.

Por fim, talvez o teatro feminista não cabia em apenas um único texto central, mas com certeza cabe em todas as falas ouvidas e ditas ao longo dessa experiência. Tivemos acesso a diversos textos que servem para escrevermos artigos e refletir sobre as diversas pautas do teatro feminista, mas também pudemos criar nossas referências, nossas vivências e nossas falas por meio de uma sensibilidade que comunga não só com nossas pesquisas, mas com nossas vidas (SILVA, 2021).

Silva mostra o quanto uma performance feminista o tocou, remexendo em suas memórias e traumas. Certamente ele não pode falar no lugar da performer, mas pode falar da sua experiência como espectador. Assim como pode falar também como filho que vivencia os preconceitos contra as crianças de mulheres consideradas "idosas".

Essas são algumas das reflexões surgidas ao longo das quatro edições da disciplina "Introdução ao Teatro Feminista" que me fazem pensar que a luta feminista pode investir muito mais em práticas artísticas e práticas do sensível. As artes da cena têm um papel fundamental nesta transformação, e por isso a urgência de que todos os nossos cursos de teatro e dança sejam engendrados pela semente feminista. Penso que esse é um caminho para convocar todas, todos e todes a refletirem sobre como nossa subjetividade é marcada pela violência do sistema patriarcal. Vale lembrar que as obras O feminismo é para todo mundo, de bell hooks, e Sejamos todos feministas, de Chimamanda Ngozi Adichie, convocam todas as pessoas a lutar pela causa feminista. Então eu proponho concluir este artigo pensando como, ao criarmos espaços na universidade para práticas e reflexões feministas, temos de desenvolver tanto ambientes ginocêntricos para acolher e fortalecer a rede de mulheres de teatro, mas também precisamos gerar espaços nos quais os homens de teatro sejam convidados a participar de práticas pedagógicas feministas. 


\section{REFERÊNCIAS}

ADICHIE, Chimamanda Ngozi. Sejamos todos feministas. São Paulo: Companhia das Letras. 2015.

AZEVEDO. Josephina Alvares de. O Voto Feminino (1890). Acervo Histórico. (sem data) 74-82. Disponível em: https://www.al.sp.gov.br/repositorio/bibliotecaDigital/525_arquivo.pdf. Acesso em 7 nov. 2021.

COSTA, Suzana Morelo Vergara Martins. Relato sobre a disciplina Introdução ao Teatro Feminista. Texto não publicado enviado por e-mail.

FABRO, Airton. Relato sobre a disciplina Introdução ao Teatro Feminista. Texto não publicado enviado por e-mail.

HANISCH, Carol. O pessoal é político. (fevereiro de 1969). Disponível em: https:// we.riseup.net/assets/190219/O+Pessoal\%2B\%C3\%A9\%2BPol\%C3\%ADtico.pdf. Acesso em 8 nov. 2021.

HOOKS, bell. O feminismo é para todo mundo: políticas arrebatadoras. Rio de Janeiro: Rosa dos Tempos. 2018.

KUMIEGA, Jennifer. The Theatre of Grotowski. London: Methuen, 1985.

MAIOR, Valéria Andrade Souto. Josefina Álvares de Azevedo - Teatro e propaganda sufragista no Brasil do século XIX. (sem data) 65-73. Disponível em: https://www.al.sp.gov.br/repositorio/bibliotecaDigital/525_arquivo.pdf. Acesso em: 7 nov. 2021.

MIRANDA, Maria Brígida de. Playful Training: Towards capoeira in the physical training of actors. Saarbrücken: LAP LAMBERT Academic Publishing. 2010.

POLIDORO, Stefanie Liz. Relato sobre a disciplina Introdução ao Teatro Feminista. Texto não publicado enviado por e-mail.

SILVA, Tiago Herculano da. Relato sobre a disciplina Introdução ao Teatro Feminista. Texto não publicado enviado por e-mail.

WOLFORD, Lisa. Grotowski's Vision of the Actor. Actor Training. Ed. Alison Hodge. London: Routledge. 2010. 199-214. 


\begin{abstract}
This article integrates an account of my experience as a professor of the subject "Introduction to Feminist Theater" and the reports of four postgraduate students from the Postgraduate Program in Theater at UDESC. I begin the text by historicizing my experience with aspects of surveillance and social control to problematize remote teaching activities in the context of the Covid-19 pandemic. I reflect on the pros and cons of interactive classes being filmed and recorded on digital platforms. Throughout the article, I combine my text with the reports of other female and male authors who shared with me their impressions and memories about this subject.
\end{abstract}

\title{
Keywords
}

Feminist theater. Remote teaching. Surveillance.

Recebido em: 16 nov. 2021

Aceito em: 16 nov. 2021

Publicado em: 16 dez. 2021 